\title{
THE CATALYTIC LOW TEMPERATURE OXYDEHYDROGENATION OF METHANE. TEMPERATURE DEPENDENCE, CARBON BALANCE AND EFFECTS OF CATALYST COMPOSITION
}

\author{
J. RASKÓ, P. PEREIRA *, G.A. SOMORJAI and H. HEINEMANN \\ Materials Science Division, Center for Advanced Materials, Lawrence Berkeley Laboratory, University \\ of California, Berkeley, CA 94720, U.S.A.
}

Received 22 March 1991; accepted 1 May 1991

\begin{abstract}
In an earlier publication [1] it has been claimed that oxidative coupling of methane to higher hydrocarbons had been obtained with close to $100 \%$ selectivity at $600^{\circ} \mathrm{C}$ and atmospheric pressure in the presence of steam over a $\mathrm{CaNiK}$ oxide catalyst. These results have been confirmed in longer runs. Artifacts, such as carbonate formation on the catalyst, have been excluded. The reaction is slightly exothermic. An Arrhenius plot shows that methane oxidation to $\mathrm{CO}_{2}$ predominates at temperatures above $600^{\circ} \mathrm{C}$ and oxidative methane coupling at lower temperatures. The importance of exact catalyst composition is demonstrated.
\end{abstract}

Keywords: Oxydehydrogenation of methane, catalytic methane conversion

\section{Introduction}

We have reported on the catalytic oxydehydrogenation of methane to ethane and ethylene in the presence of excess steam as $600^{\circ} \mathrm{C}$ over a $\mathrm{CaNiK}$-oxide catalyst with a composition of $2: 1: 0.1$ [1]. The selectivity to $\mathrm{C}_{2}$ hydrocarbons was nearly $100 \%$ and the conversion was $10-12 \%$ under our conditions of the experiments. In this paper we present more data obtained by the continued characterization of the catalyst. Temperature dependent studies revealed that the overall activation energy is $83 \mathrm{~kJ} /$ mole for producing about $60 \%$ ethane and $40 \%$ ethylene and this reaction predominates below $600^{\circ} \mathrm{C}$ as compared to methane steam reforming and $\mathrm{CO}_{2}$ formation which becomes dominant at higher temperatures. We obtained a carbon balance of $100 \%$ under various experimental conditions on the active catalysts. We also varied the $\mathrm{Ca}: \mathrm{Ni}: \mathrm{K}$ ratio over a wide range and report here the effects of catalyst composition on the reaction activity and on the catalyst deactivation properties. The oxide catalyst with a composition of $\mathrm{Ca}_{2-4} \mathrm{Ni}_{1} \mathrm{~K}_{0.1}$ appears to be the most active and selective under our conditions of the methane coupling reaction.

* INTEVEP, S.A.; Apartado 76343, Caracas 1070A, Venezuela.

(1) J.C. Baltzer A.G. Scientific Publishing Company 


\section{Experimental}

Catalyst preparation started with mixing of appropriate amounts of $\mathrm{Ca}\left(\mathrm{NO}_{3}\right)_{2}$ $\left.\times 4 \mathrm{H}_{2} \mathrm{O}\right)\left(\right.$ Mallinckrodt), $\left.\mathrm{Ni}\left(\mathrm{NO}_{3}\right)_{2} \times 6 \mathrm{H}_{2} \mathrm{O}\right)\left(\right.$ Fischer Scientific Co.) and $\mathrm{KNO}_{3}$ (Mallinckrodt). The well-homogenized nitrate mixture was heated in air at $120^{\circ} \mathrm{C}$ for about 14 hours. The mixture melted and gradually lost its water content. The dried mixture was heated stepwise at $350^{\circ} \mathrm{C}$ for 2 hours, at $550^{\circ} \mathrm{C}$ for 2 hours and was finally decomposed under flowing air (flow rate: $2 \mathrm{cc} / \mathrm{min}$ ) at $700^{\circ} \mathrm{C}$ for 18 hours.

The apparatus used is shown in fig. 1. Methane and oxygen were obtained from Matheson (their purities were better than 99.99\%). A Harvard syringe pump was used for pumping distilled water to the reactor through a pipe which was heated at $140^{\circ} \mathrm{C}$.

The catalyst was oxidized in the reactor with flowing oxygen (flow rate: 2 $\mathrm{cc} / \mathrm{min})$ at $680^{\circ} \mathrm{C}$ for 18 hours before starting experiments. The methaneoxygen-steam gas mixture molar ratio of $\mathrm{CH}_{4}: \mathrm{O}_{2}: \mathrm{H}_{2} \mathrm{O}=3: 1: 6.5$ ) was introduced to the reactor at $580-750^{\circ} \mathrm{C}$. The methane space velocity was $4.0 \mathrm{mmol} / \mathrm{g}$ catalyst/hr.

Products of the reaction were analyzed by gas chromatography using FID, TCD and mass spectrometer detectors.

Gases on input and output side were controlled and measured by control valves and mass flow meters.

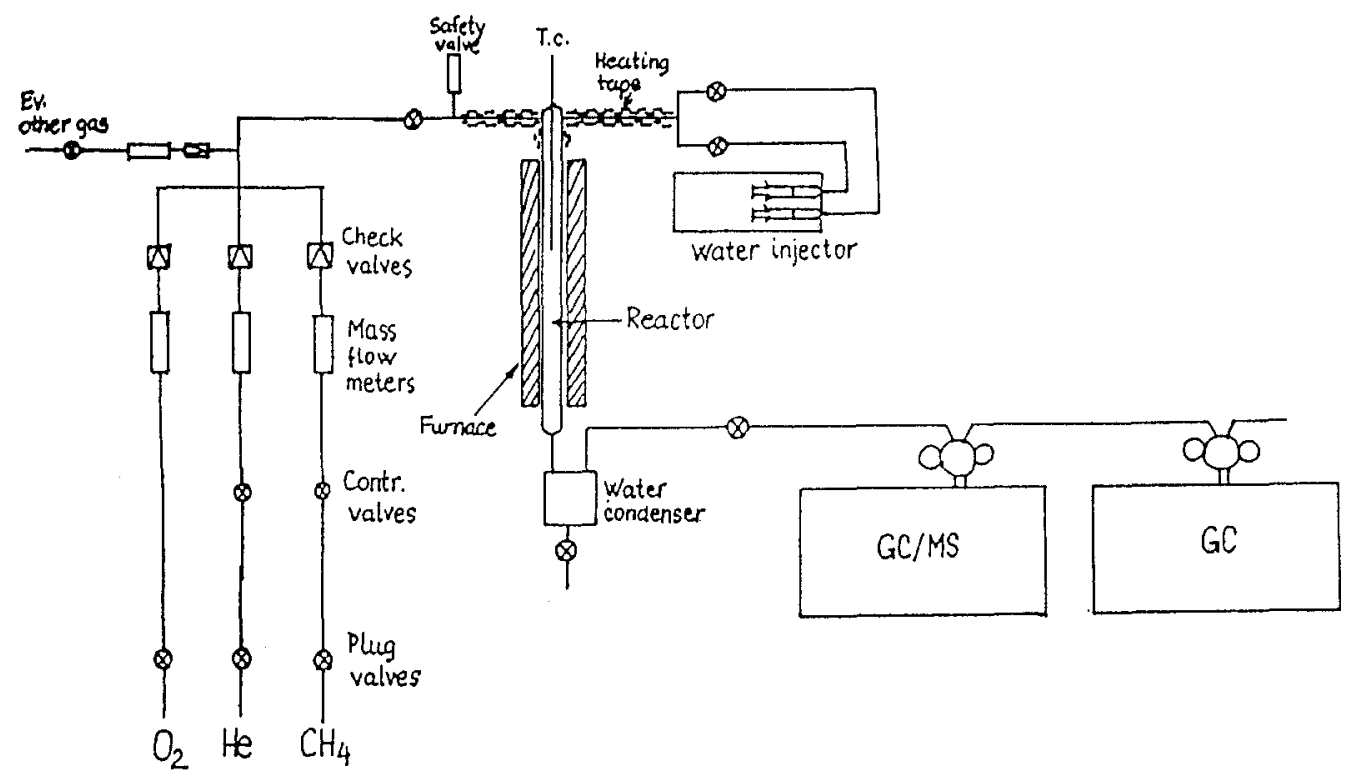

Fig. 1. Flow reactor scheme. 


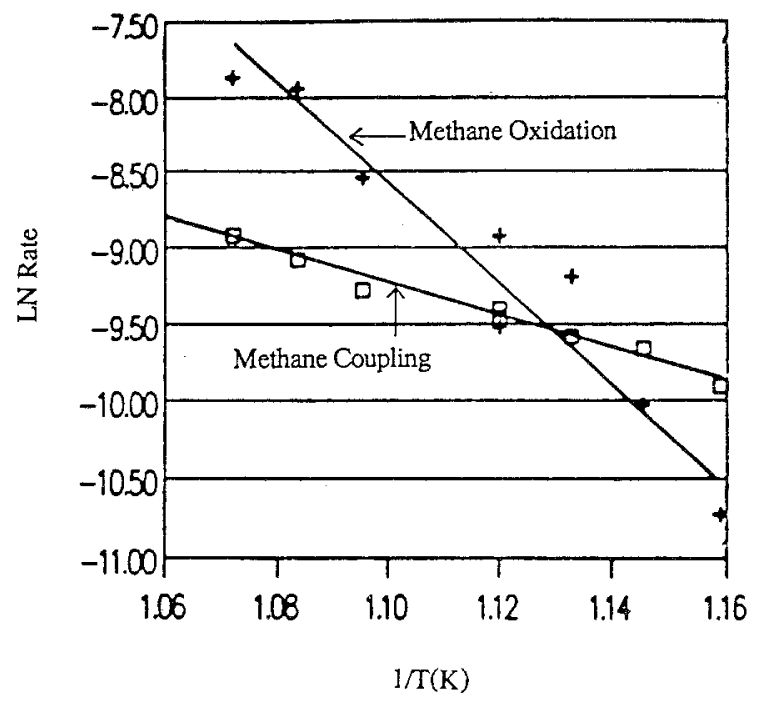

Fig. 2. Arrhenius plot $\left(580-660^{\circ} \mathrm{C}\right)$ for methane oxydehydrogenation and methane oxidation.

A. The activation energy and thermodynamic consideration for methane conversion

Fig. 2 shows the conversion $\log$ rate vs. temperature for producing ethane and ethylene. The activation energy is $83 \mathrm{~kJ} /$ mole. The same figure also shows the activation energy found for methane steam reforming under our conditions of the experiment. It appears that below $600^{\circ} \mathrm{C}$ the oxidative coupling reaction dominates. Only above this temperature does $\mathrm{CO}_{2}$ formation which has a much higher activation energy of $263 \mathrm{~kJ} /$ mole become significant. In fig. 3 we compare the heats of reaction for five different reactions of methane as a function of temperature. The oxydehydrogenation reactions to produce ethane and ethylene are somewhat exothermic as compared to the highly endothermic steam reforming or the highly exothermic combustion reactions. We find that by using both steam and oxygen we could inhibit both steam reforming and combustion over our catalyst which then is capable of producing ethane and ethylene.

B. The carbon balance during the catalytic conversion of methane to ethane and ethylene

A careful carbon balance was performed to insure that analytical results would not be influenced by a potential absorption of $\mathrm{CO}_{2}$ produced by the catalyst with formation of calcium carbonate. Carbon input (as methane) and carbon output (as methane, higher hydrocarbons and $\mathrm{CO}_{x}$ ) were metered and analyzed. Table 1 shows the carbon balance for two runs, one at high selectivity and the other at relatively poor selectivity. A blank run with an empty reactor at the same conditions gave 0.8 to $1.0 \%$ conversion to $\mathrm{CO}_{2}$. This corresponds exactly to the $\mathrm{CO}_{2}$ selectivities obtained with catalyst in the reactor $(8-10 \%$ at $10 \%$ conversion, table 1), and indicates that $\mathrm{CO}_{2}$ was formed thermally and none was absorbed on 


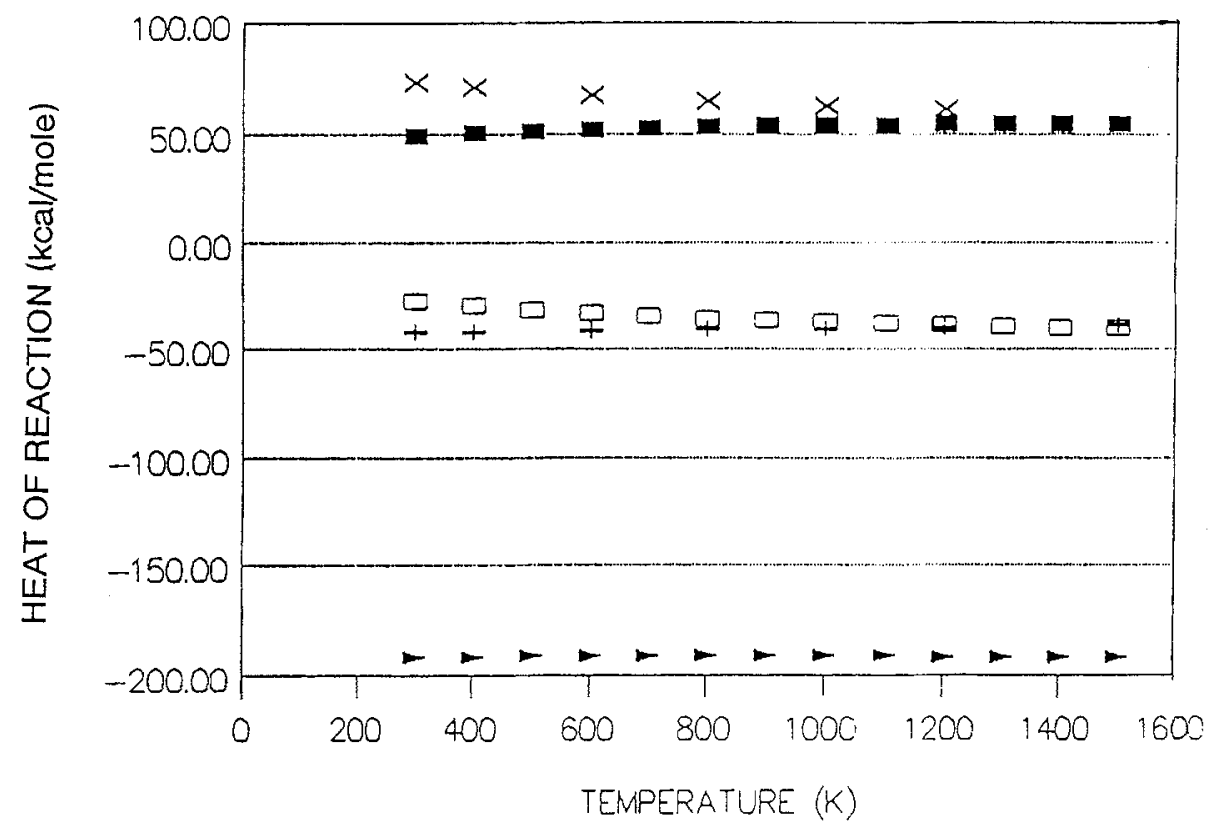

Fig. 3. Heat of reaction at different temperatures: combustion $\downarrow$, ethane dehydrogenation $x$, steam reforming $\square$, oxydehydrogenation to ethane + , and ethylene $\square$.

the catalyst. Excellent balances were obtained. An oxygen balance is difficult to obtain because water formed during oxidative coupling is a small fraction of the water used as steam.

C. The effects of variations of composition on the activity, selectivity and deactivation of the CaNiK-oxide catalysts.

$\mathrm{CaO}, \mathrm{CaK}_{0.1} \mathrm{O}_{x}, \mathrm{Ca}_{3} \mathrm{NiO}_{x}, \mathrm{NiK}_{0.1} \mathrm{O}_{x}$ and $\mathrm{Ca}_{3} \mathrm{NiK}_{0.1} \mathrm{O}_{x}$ catalysts were tested at the same reaction conditions $\left.\left(600^{\circ} \mathrm{C}, \mathrm{CH}_{4}: \mathrm{O}_{2}: \mathrm{H}_{2}\right)=3: 1: 6.5\right)$. The results obtained are shown in table 2 .

Table 1

Carbon balance for two runs at different conversion and selectivity values $\mathrm{Ca}_{3} \mathrm{Ni}_{1} \mathrm{~K}_{0.1}$ catalyst $\mathrm{C}_{\text {output }} / \mathrm{C}_{\text {input }}$

\begin{tabular}{lclllc}
\hline Catalyst & $\begin{array}{l}\text { Time } \\
(\mathrm{min})\end{array}$ & $\begin{array}{l}\text { Conversion } \\
(\%)\end{array}$ & $\begin{array}{l}\text { Hydrocarbon } \\
\text { selectivity }(\%)\end{array}$ & $\begin{array}{l}\mathrm{CO}_{x} \\
\text { sel }(\%)\end{array}$ & $\begin{array}{c}\text { Carbon } \\
\text { balance }\end{array}$ \\
\hline $\mathrm{A}$ & 60 & 10 & 93 & 7 & 99.8 \\
$\mathrm{~A}$ & 120 & 10 & 92 & 8 & 100.1 \\
$\mathrm{~B}$ & 50 & 4 & 80.3 & 20 & 101.8 \\
$\mathrm{~B}$ & 130 & 5 & 48.3 & 52 & 104.7 \\
$\mathrm{~B}$ & 165 & 3 & 83.3 & 17 & 101.3 \\
$\mathrm{~B}$ & 205 & 4 & 56.9 & 43 & 101.3 \\
$\mathrm{~B}$ & 245 & 3 & 78.9 & 21 & 98.6 \\
\hline
\end{tabular}


Table 2

Methane oxidative coupling run. Conversion and selectivities $\mathrm{Ca}_{4} \mathrm{Ni}_{1} \mathrm{~K}_{0.1}$ catalyst $600^{\circ} \mathrm{C}$; $\mathrm{CH}_{4}: \mathrm{O}_{2}: \mathrm{H}_{2} \mathrm{O}=3: 1: 6$; atm. pressure

\begin{tabular}{cccc}
\hline $\begin{array}{l}\text { Time } \\
(\min )\end{array}$ & $\begin{array}{l}\mathrm{CH}_{4} \text { conv. } \\
(\%)\end{array}$ & $\begin{array}{l}\text { Hyd. sel. } \\
(\%)\end{array}$ & $\begin{array}{l}\mathrm{CO}_{x} \text { sel. } \\
(\%)\end{array}$ \\
\hline 95 & 10.6 & 91 & 9 \\
153 & 9.3 & 92 & 8 \\
212 & 9.2 & 92 & 7 \\
271 & 10.0 & 93 & 7 \\
329 & 8.8 & 88 & 11 \\
388 & 9.3 & 92 & 8 \\
\hline
\end{tabular}

$\mathrm{CaO}$ alone produced mainly $\mathrm{CO}_{2}$ and $\mathrm{CO}(82.0-77.2 \%$ and $7.0-11.0 \%$, resp.); only $9.0-11.4 \%$ selectivity for hydrocarbons was found at a conversion of 4.8-2.3\%. Introducing a small amount of potassium onto $\mathrm{CaO}$, the hydrocarbon selectivity increased up to $80 \%$ at a conversion of $4.7-4.6 \%$. The presence of potassium suppressed $\mathrm{CO}_{2}$ and $\mathrm{CO}$ formation. This is also reflected in the results obtained on $\mathrm{Ca}_{3} \mathrm{NiO}_{x}$ (without potassium) where the starting value of hydrocarbon selectivity (43.7\%) decreased considerably with time on stream, while $\mathrm{CO}_{2}$ formation became dominant. On $\mathrm{NiK}_{0.1} \mathrm{O}_{x}$ a relatively high conversion (16.9$15.6 \%$ ) was observed; the main reaction product was $\mathrm{CO}_{2}$ (i.e., total oxidation was dominant). The most active and selective catalyst proved to be $\mathrm{Ca}_{3} \mathrm{NiK}_{0.1} \mathrm{O}_{x}$.

It is interesting to note that in the presence of potassium (see $\mathrm{CaK}_{0.1} \mathrm{O}_{x}$ ) a small amount of $\mathrm{CO}$ was observed. It can be inferred that steam reforming of $\mathrm{CH}_{4}$ occurs on $\mathrm{CaK}_{0.1} \mathrm{O}_{x}$. The absence of $\mathrm{CO}$ among the reaction products in the presence of $\mathrm{Ni}$ may indicate the ability of $\mathrm{Ni}$ to oxidize $\mathrm{CO}$ to $\mathrm{CO}_{2}$ in the presence of oxygen.

D. The conversion of $\mathrm{CH}_{4}$ to higher hydrocarbons

Table 3 presents results from a typical run at $600^{\circ} \mathrm{C}$ during 6.5 hours. Conversion was quite steady as was selectivity at $\approx 92 \%$. It is important to point

Table 3

Methane oxidative coupling run; product distribution $\mathrm{Ca}_{4} \mathrm{Ni}_{1} \mathrm{~K}_{0.1}$ catalyst $600^{\circ} \mathrm{C} ; \mathrm{CH}_{4}: \mathrm{O}_{2}: \mathrm{H}_{2} \mathrm{O}$ $=3: 1: 6$; atm. pressure

\begin{tabular}{rllllll}
\hline $\begin{array}{l}\text { Time } \\
(\min )\end{array}$ & $\begin{array}{l}\mathrm{C}_{2} \mathrm{H}_{4} \\
\text { sel }(\%)\end{array}$ & $\begin{array}{l}\mathrm{C}_{2} \mathrm{H}_{6} \\
\operatorname{sel}(\%)\end{array}$ & $\begin{array}{l}\mathrm{C}_{3} \mathrm{H}_{6} \\
\text { sel }(\%)\end{array}$ & $\begin{array}{l}\mathrm{C}_{3} \mathrm{H}_{8} \\
\text { sel (\%) }\end{array}$ & $\begin{array}{l}\mathrm{C}_{4} \\
\text { sel (\%) }\end{array}$ & $\begin{array}{l}\text { Par/01 } \\
\text { ratio }\end{array}$ \\
\hline 95 & 42 & 40 & 3 & 4 & 2 & 0.98 \\
153 & 40 & 41 & 4 & 4 & 3 & 1.0 \\
212 & 40 & 41 & 5 & 4 & 3 & 1.0 \\
271 & 39 & 42 & 5 & 4 & 3 & 1.1 \\
329 & 44 & 33 & 5 & 4 & 2 & 0.8 \\
388 & 41 & 40 & 5 & 3 & 3 & 1.0 \\
\hline
\end{tabular}


Table 4

Characteristic data of $\mathrm{CH}_{4}$ coupling on different catalysts $600^{\circ} \mathrm{C} ; \mathrm{CH}_{4}: \mathrm{O}_{2}: \mathrm{H}_{2} \mathrm{O}=3: 1: 6.5$; atm. pressure

\begin{tabular}{lrrlll}
\hline Catalyst & Conversion & \multicolumn{1}{c}{$\mathrm{HC}$ sel. } & \multicolumn{1}{c}{$\mathrm{CO}_{2}$ sel. } & $\mathrm{CO}$ sel. & $\mathrm{CO}_{x}$ sel. \\
\hline $\mathrm{CaO}(8.5 \%)$ & $4.8-2.3 \%$ & $9.0-11.4 \%$ & $83.0-77.5 \%$ & $7.0-11.0 \%$ & $90.0-$ \\
$\mathrm{CaK}_{0.1}(20 \%)$ & $4.7-4.6 \%$ & $81.5-79.9 \%$ & $16.6-17.5 \%$ & $1.8-2.5 \%$ & $18.5-$ \\
$\mathrm{Ca}_{3} \mathrm{Ni}$ & $3.1-6.7 \%$ & $43.7-11.0 \%$ & $56.2-88.9 \%$ & 0 & \\
$\mathrm{NiK}_{0.1}$ & $16.9-15.6 \%$ & $2.1-2.3 \%$ & $97.8-97.6 \%$ & 0 & \\
$\mathrm{Ca}_{3} \mathrm{NiK}_{0.1}$ & $9.9-9.0 \%$ & $93.7-91.1 \%$ & $6.3-8.9 \%$ & 0 & \\
\hline
\end{tabular}

out that blank runs with an empty reactor at the same conditions gave $0.7-1.0 \%$ conversion of $\mathrm{CH}_{4}$ to $\mathrm{CO}_{2}$. This amount of $\mathrm{CO}_{2}$ would correspond to 7-10\% $\mathrm{CO}_{2}$ selectivity at $10 \%$ conversion or about what is observed in runs with a catalyst.

Table 4 gives a product distribution of the same run as in table 3. Again all selectivities were steady. Small amounts of $\mathrm{C}_{3}$ and $\mathrm{C}_{4}$ hydrocarbons were formed and the olefin/paraffin ratio was about 1.0.

The longest run thus far made lasted about 19 hours. It showed only a small decline in activity and selectivity, probably due to a unit upset after $10 \mathrm{hrs}$.

\section{Discussion}

The activation energy for producing ethane is low compared to the $\Delta E^{*}$ for steam reforming. The coupling reaction appears to dominate at low temperatures below $600^{\circ} \mathrm{C}$. It is interesting to note that the activation energy is similar to that found for methanation or for the formation of low molecular weight hydrocarbons from $\mathrm{CO}$ and $\mathrm{H}_{2}$. In that reaction the dominant mechanism appears to be the dissociation of $\mathrm{CO}$ by the Boudouard reaction $\left(2 \mathrm{CO} \rightarrow \mathrm{C}+\mathrm{CO}_{2}\right)$ and the subsequent hydrogenation of the surface carbon to $\mathrm{CH}_{x}$ species that may fully hydrogenate to methane or couple to produce $\mathrm{C}_{2}, \mathrm{C}_{3} \ldots$ hydrocarbons. Although we do not have enough kinetic information to verify the mechanisms of $\mathrm{CH}_{x}$-coupling, it is possible that methane is both the source of $\mathrm{CH}_{x}$ intermediates and of $\mathrm{H}$ atoms on the surface. The former may couple to produce $\mathrm{C}_{y} \mathrm{H}_{x}$ species by a mechanism similar to that in the Fischer-Tropsch reaction while the surface hydrogen produces water. It would be interesting to extend the range of reaction and to lower the temperature and explore other catalyst compositions in order to obtain products other than $\mathrm{C}_{2}$ just as in the case of Fischer-Tropsch reactions. In any case the breaking of the first $\mathrm{C}-\mathrm{H}$ bond in $\mathrm{CH}_{4}$ does not appear to need the high temperature $\left(>650^{\circ} \mathrm{C}\right)$ as was originally thought [2]. It appears that by the simultaneous use of both oxygen and water both the combustion and the steam reforming reactions, one highly exothermic, the other highly endothermic can be 
inhibited. In this circumstance the oxidative coupling of methane can be the dominant reaction path over the $\mathrm{Ca}_{2-4} \mathrm{Ni}_{1} \mathrm{~K}_{0.1} \mathrm{O}_{x}$ catalyst.

The carbon balance of nearly $100 \%$ within the experimental error clearly indicates that the reaction is catalytic and the catalyst does not behave as a possible reactant. This was important to determine since the formation of carbonates could be blamed for the lack of $\mathrm{CO}_{2}$ formation. This, however, is not the case. Another indication of the non-absorption of $\mathrm{CO}_{2}$ on the catalyst is the fact that $\mathrm{CaCO}_{3}$ is stable up to $900^{\circ} \mathrm{C}$. A catalyst prepared from $\mathrm{CaCO}_{3}$ was essentially inactive after calcination at $750^{\circ} \mathrm{C}$ but became active after $900^{\circ} \mathrm{C}$ calcination. When the $\mathrm{Ca}_{3} \mathrm{NiK}_{0.1}$ catalyst loses activity, it can readily be reactivated by $\mathrm{O}_{2}$ treatment at $700^{\circ} \mathrm{C}$. The fact that $\mathrm{CO}_{2}$ production is the same from an empty reactor and from a catalytic run shows that essentially no $\mathrm{CO}_{2}$ is produced over the catalyst and that selectivity to hydrocarbons is at or close to $100 \%$.

The most active catalyst composition for the selective coupling of methane is $\mathrm{Ca}_{2-4} \mathrm{Ni}_{1} \mathrm{~K}_{0.1} \mathrm{O}_{x}$ as shown by our experiments. However, $\mathrm{Ca}_{3} \mathrm{~K}_{0.1} \mathrm{O}_{x}$ exhibits significant activity and selectivity that indicates that the surface chemistry leading to $C_{2}$ hydrocarbons from methane does not need the presence of nickel which acts as a promoter.

$\mathrm{CaO}$ alone is a poor catalyst and $\mathrm{NiO}$ and $\mathrm{KO}_{x}$ do not produce $\mathrm{C}_{2}$ hydrocarbons. Further studies will explore the mechanism of this reaction with $\mathrm{Ca}_{2-4} \mathrm{Ni}_{1} \mathrm{~K}_{0.1} \mathrm{O}_{x}$ and the promoter action of other transition metal oxides on the selectivity and activity of this catalyst. It should be noted that $\mathrm{CaKO}_{x}$ is also an outstanding catalyst for the steam gasification of graphite and char at relatively low temperatures to $\mathrm{H}_{2}$ and $\mathrm{CO}_{2}$ [3].

\section{Acknowledgement}

This work was supported by the Assistant Secretary for Fossil Energy, Office of Management Planning and Technical Coordination, Technical Division of the U.S. Department of Energy under contract No. DE-AC03-76SF00098, through the Morgantown Energy Technology Center, Morgantown, WV 26505.

\section{References}

[1] P. Pereira, S.H. Lee, G.A. Somorjai and H. Heinemann, Catal. Lett. 6 (1990) 255.

[2] Y. Amenomiya, V.I. Birss, M. Goledzinowski, J. Galuszka and A.R. Sanger, Catal. Rev. Sci-Eng. 32 (1990) 163.

[3] P. Pereira, R. Csencsits, G.A. Somorjai and H. Heinemann, J. Catal. 123 (1990) 463. 